\title{
Nutrient Accumulation and Associated Root Characteristics in Response to Drought Stress in Tall Fescue Cultivars
}

\author{
Bingru Huang ${ }^{1}$ \\ Department of Horticulture, Forestry and Recreation Resources, Kansas State \\ University, Manhattan, KS 66506-5506 \\ Additional index words. drought tolerance, Festuca arundinacea, mineral nutrition, root \\ growth, water relations
}

\begin{abstract}
Drought is a major factor limiting the growth of turfgrasses in many areas. The functional relationship of drought stress and accumulation of various ions in turfgrasses is not well understood. The objective of this study was to investigate the effects of drought on root growth and accumulation of several major nutrients in three tall fescue (Festuca arundinacea Schreb.) cultivars varying in drought tolerance (Falcon II = Houndog V > Rebel Jr). Grasses were grown in well-watered or drying (nonirrigated) soil for 35 days in a greenhouse. Drought conditions limited total root length to a greater extent for 'Rebel Jr' than for 'Falcon II' and 'Houndog V', while specific root length (SRL) was greater in 'Falcon II' and 'Houndog V' than in 'Rebel Jr'. Concentrations of N, P, and Mg decreased, whereas those of $\mathrm{K}, \mathrm{Ca}$, and $\mathrm{Fe}$ increased, in shoots of drought-stressed plants of all three cultivars. Root $\mathrm{N}$ was not affected, but root $\mathrm{P}$ decreased in 'Rebel $\mathrm{Jr}$ ', and root $\mathrm{K}$ decreased in all three cultivars under drought conditions. Drought reduced the proportions of $\mathrm{N}$ and $P$ in shoots and increased those in roots, while increasing the proportion of $K$ in shoots and decreasing that in roots. During drought stress, both 'Falcon II' and 'Houndog V' maintained higher $\mathrm{K}$ concentration in shoots, and 'Falcon II' in roots, than did 'Rebel Jr', but 'Rebel Jr' and 'Houndog V' had higher Fe concentration in shoots than did 'Falcon II'. The higher $\mathrm{K}$ and lower $\mathrm{Fe}$ accumulations in shoots could contribute to better drought tolerance of tall fescue cultivars.
\end{abstract}

Drought stress adversely affects many physiological processes of plants, including nutrient metabolism. Maintenance of nutrient uptake capacity in drying soil increases plant tolerance to drought (Matzner and Richards, 1996). Lack or excessive accumulation of nutrients can lead to inhibitory effects on many other physiological processes. Heckathorn et al. (1997) reported that loss of photosynthetic capacity in $\mathrm{C}_{4}$ prairie grasses during drought is largely the result of reductions in shoot $\mathrm{N}$ accumulation. Accumulation of Fe during drought stress can damage physiological functions of cells by activating lipid peroxidation of cell membranes (Price and Hendry, 1991).

Because of its drought tolerance, tall fescue, a cool-season grass, is widely used as a turfgrass for home lawns and commercial landscapes in the transitional zone and in cool, temperate climates (Beard, 1989). White et al. (1992, 1993) suggested that drought avoidance of tall fescue cultivars is conferred by total root length, and drought tolerance is

Received for publication 16 Dec. 1999. Accepted for publication 8 June 2000. Contribution 00-199-J from the Kansas Agricultural Experiment Station. This research was supported by the Kansas Agricultural Experiment Station and Kansas Turfgrass Foundation. The cost of publishing this paper was defrayed in part by the payment of page charges. Under postal regulations, this paper therefore must be hereby marked advertisement solely to indicate this fact. ${ }^{1}$ Assistant Professor. Current address: Dept. of Plant Science, Rutgers Univ., New Brunswick, NJ 08901. E-mail address: Huang@ aesop.rutgers.edu conferred by low basal osmotic potential. Studies by Huang et al. (1998) and Huang and Gao (1999) suggested that maintenance of high photosynthetic and transpiration rates and high stomatal conductance facilitates drought tolerance in several tall fescue cultivars. Various studies have demonstrated that morphological and physiological characteristics of roots that influence water uptake can have a significant impact on drought tolerance in turfgrasses (Carrow, 1996; Huang, 1998; Huang and Fry, 1998; Huang et al., 1997; Huang and Gao, 2000; Marcum et al., 1995; Qian and Fry, 1997; Sheffer et al., 1987). However, the differential effects of soil drying on nutrient content and associated root characteristics in tall fescue cultivars are not well understood, and a better understanding of such responses might facilitate breeding and management programs to improve their drought resistance.

The objectives of this study were to: 1) determine and compare the responses of root growth and nutrient accumulation in tall fescue cultivars differing in drought tolerance; and 2) investigate the extent to which drought stress influences uptake and partitioning of different nutrients.

\section{Materials and Methods}

Three tall fescue cultivars, 'Falcon II', 'Houndog V', and 'Rebel Jr', were examined. 'Falcon II' and 'Houndog V' are relatively more tolerant to drought than is 'Rebel Jr' (Huang and Gao, 1999, 2000).
Sod pieces $15 \mathrm{~cm}$ in diameter and $3 \mathrm{~cm}$ deep of each cultivar were collected from 5-year-old plots at the Rocky Ford Turfgrass Research Center, Kansas State Univ., Manhattan. Sod pieces were scraped and washed free of soil before planting in $15-\mathrm{cm}$-diameter $\times 60$-cm-deep polyvinyl chloride (PVC) tubes filled with a mixture of 1 coarse river sand : 2 silt loam soil (fine, montmorillonitic, mesic, Aquic, Arquidolls) (v/v) collected from the field. The soil had a $\mathrm{pH}$ of 6.6 and organic matter content of $2.2 \%$. The contents of $\mathrm{N}, \mathrm{P}$, $\mathrm{K}, \mathrm{Ca}, \mathrm{Mg}$, and Fe in the soil were 106, 13, 176, 1780,208 , and $47 \mathrm{mg} \cdot \mathrm{kg}^{-1}$, respectively.

Plants were grown from Feb. to May 1998 in a greenhouse with daily maximum/ minimum temperatures of $24 / 15{ }^{\circ} \mathrm{C}$ and a photoperiod of $14 \mathrm{~h}$. The light regime was supplemented with $1 \mathrm{~kW}$ metal halide lamps placed $1.5 \mathrm{~m}$ above the turf canopy. Photosynthetically active radiation $(P A R)$ on a horizontal plane just above the canopy at noon averaged $800 \mu \mathrm{mol} \cdot \mathrm{m}^{-2} \cdot \mathrm{s}^{-1}$ during the experimental period. Plants were watered twice weekly to bring soil to near field capacity for 2 months before the drying treatment began. Controlled-release fertilizer with ammoniacal $\mathrm{N}(17 \mathrm{~N}-6 \mathrm{P}-10 \mathrm{~K})$ was topdressed twice during the 2-month period when plants were irrigated to provide a total of $17 \mathrm{~g} \cdot \mathrm{m}^{-2} \mathrm{~N}$. Turf was handclipped twice weekly at a 6-cm height. Clippings were returned to the pots.

The experiment consisted of two soil moisture treatments: 1) well-watered control (plants were irrigated every other day until free drainage occurred from the bottom of the containers); and 2) drought stress (irrigation was withheld, and soil was allowed to dry for $35 \mathrm{~d}$ ). Volumetric soil water content in the 0-20and 40-60-cm layers of soil was measured using time-domain reflectometry (TDR) (Soil Moisture Equipment, Santa Barbara, Calif.). The field capacity of the soil at $0-20$ and 40$60 \mathrm{~cm}$ averaged $30 \% \pm 2 \%$ (mean of four replications $+\mathrm{SE}$ ), which was measured in four PVC tubes with TDR when drainage ceased following watering to complete saturation. Soil water content on the $0-20 \mathrm{~cm}$ soil layer had declined to $\approx 5 \%$ ( $17 \%$ of FC) after $35 \mathrm{~d}$ of drought.

During the 35-d treatment period, various physiological characteristics of shoot and root were measured, and the results have been reported (Huang and Gao, 1999, 2000). At the end of the 35-d dry-down period, all plants in each container were harvested, and shoots were separated from roots. Roots were washed free of soil. Length of all roots in each container was measured with an image analysis system (Decagon, Pullman, Wash.). Shoots and roots were oven-dried at $85^{\circ} \mathrm{C}$ for $72 \mathrm{~h}$ until no further weight loss occurred. Root dry weight was determined, and specific root length (SRL = root length per unit root weight) was calculated. Dry shoots and roots were then ground with a cyclone sample mill (UDY Corp., Fort Collins, Colo.) to pass a 40-mesh screen. Shoots were analyzed for concentrations of $\mathrm{N}, \mathrm{P}, \mathrm{K}, \mathrm{Ca}, \mathrm{Mg}$, and $\mathrm{Fe}$. Roots were analyzed for only $\mathrm{N}, \mathrm{P}$, and $\mathrm{K}$ because of the limited quantity of tissue. Total $\mathrm{N}$ concentra- 
tions in shoots and roots were determined using the Kjeldahl method (McKenzie, 1953) and a $\mathrm{N}$ autoanalyzer (Technicon, Tarrytown, N.Y.). Concentrations of $\mathrm{P}, \mathrm{K}, \mathrm{Ca}, \mathrm{Mg}$, and $\mathrm{Fe}$ were determined in the digest using inductively coupled plasma emission spectroscopy (Accuris 141; Thermo Optek Corp., Atlanta, $\mathrm{Ga}$.). The quantity of each nutrient element in shoots or roots was calculated as a proportion of the total amount of nutrient in the whole plant (shoots and roots) to examine the nutrient allocation pattern.

The experiment involved two factors (three cultivars and two soil moisture treatments) with four replications arranged in a completely randomized design. Treatment effects were determined by analysis of variance (ANOVA) according to the general linear models procedure of the Statistical Analysis System (SAS Institute, Cary, N.C.). Variation was partitioned into cultivar and soil moisture as main effects and their corresponding interactions. When interaction was significant, only individual treatments within cultivars were compared. Differences between soil moisture treatments in the concentration of each nutrient for each cultivar were separated by a protected least significant difference (LSD, $P \leq 0.05$ ) test.

\section{Results}

Root growth. Drought stress reduced total root length in all three cultivars (Fig. 1). Root length did not differ among cultivars under well-watered conditions, but was greater in 'Falcon II' and 'Houndog V' than in 'Rebel Jr' under drought conditions.

The SRL of all cultivars increased with soil depth under drought conditions (Fig. 2). Under well-watered conditions, cultivars did not differ in SRL in the $0-20$ and $40-60 \mathrm{~cm}$ soil layers, but 'Houndog V' had a higher SRL than did 'Falcon II' and 'Rebel Jr' in the 20 $40 \mathrm{~cm}$ layer. Cultivar differences in SRL varied with soil depth; in the 0-20-cm layer, SRLs of 'Falcon II' and 'Houndog V' did not differ significantly but were higher than that of 'Rebel Jr'; in the 20-40-cm layer, the SRL of 'Houndog V' was significantly higher than that of 'Rebel Jr' but did not differ from that of Falcon II; in the 40-60-cm layer, SRLs were did not differ significantly among cultivars.

Shoot nutrient status. Drought reduced the concentrations of $\mathrm{N}, \mathrm{P}$, and $\mathrm{Mg}$ in shoots of all three cultivars (Table 1); the reduction was greater for $\mathrm{P}(30 \%$ to $40 \%)$ than for $\mathrm{N}$ and $\mathrm{Mg}$ (10\%). Under drought conditions, the P concentration of 'Falcon II' was significantly higher than that of 'Rebel Jr' but did not differ from that of 'Houndog V'; $\mathrm{N}$ and $\mathrm{Mg}$ concentrations did not differ among cultivars.

Concentrations of $\mathrm{K}, \mathrm{Ca}$, and $\mathrm{Fe}$ in shoots increased under drought conditions in all three cultivars. The $\mathrm{K}$ concentration was significantly higher in 'Falcon II' and 'Houndog V' than in 'Rebel Jr', whereas the Fe concentration was higher in 'Rebel Jr' and 'Houndog V' than in 'Falcon II'. Cultivars did not differ in $\mathrm{Ca}$ concentrations in shoots under drought conditions. Under control conditions, concen-

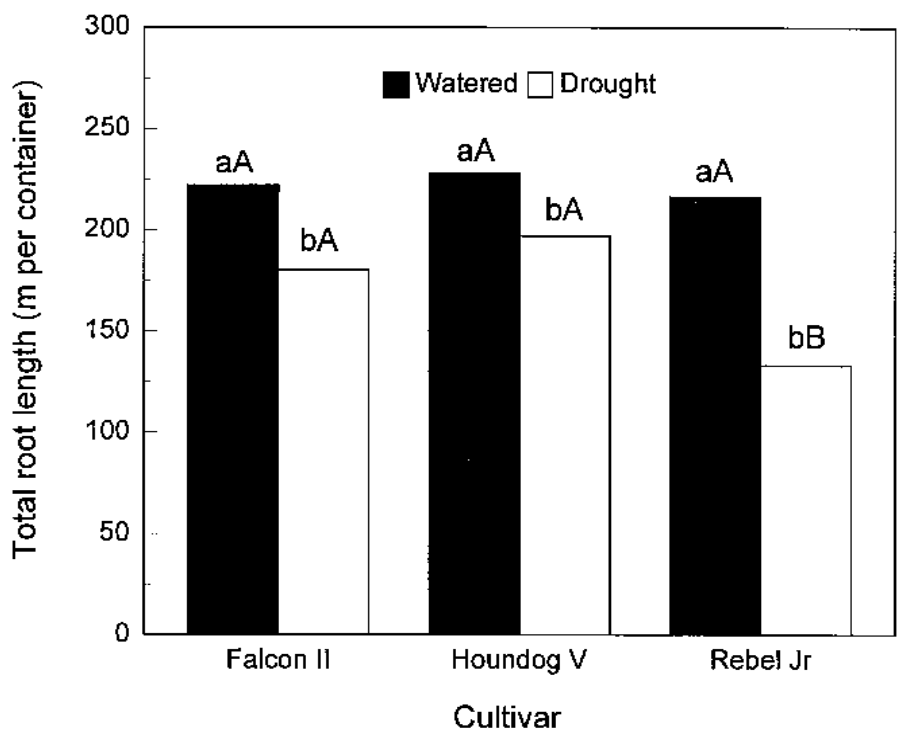

Fig. 1. Total root length of three tall fescue cultivars as affected by drought stress. Columns with the same letters are not significantly different based on LSD $(P \leq 0.05)$. Lowercase letters indicate treatment comparisons within a given cultivar, and uppercase letters indicate cultivar comparisons within a given treatment.

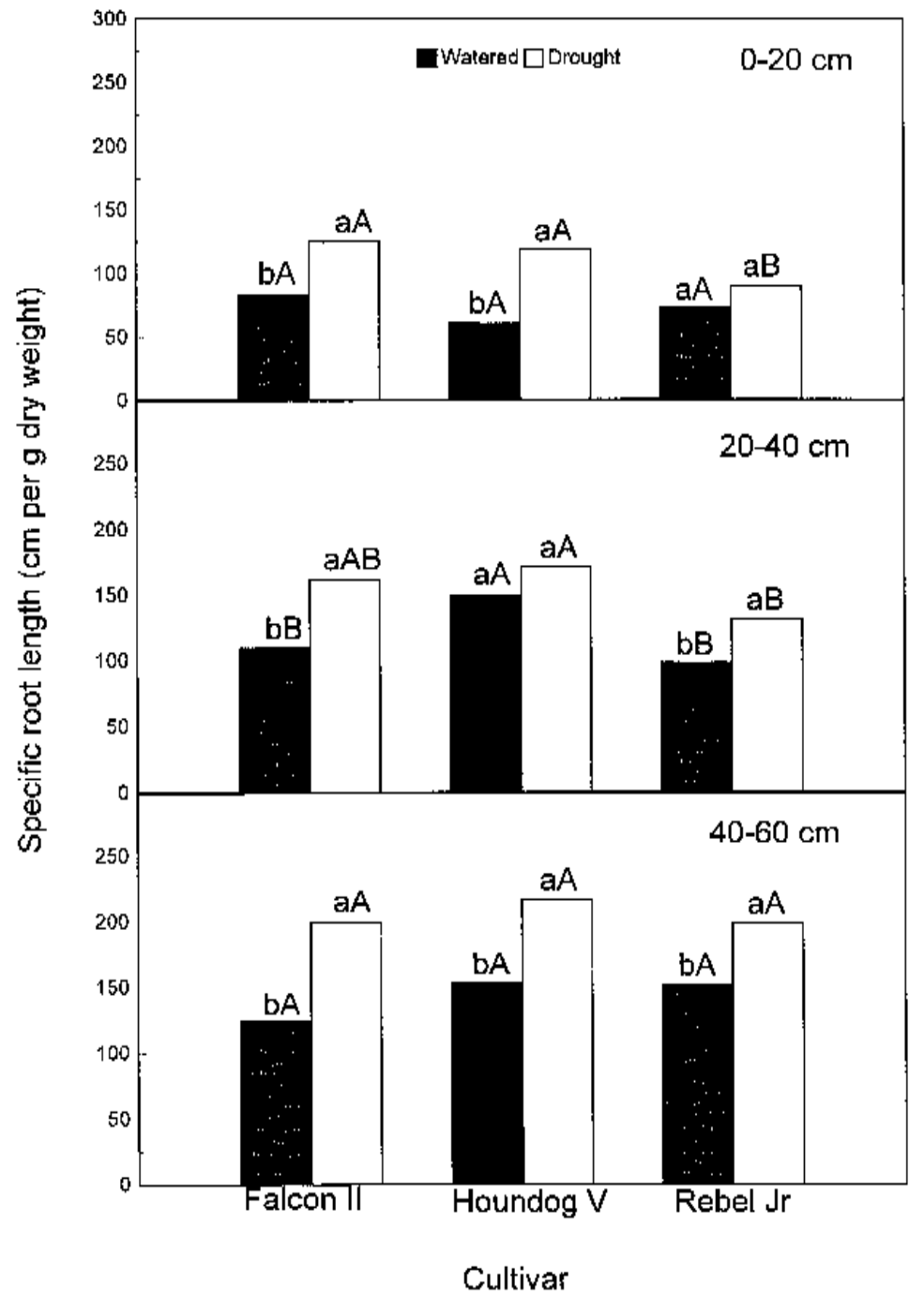

Fig. 2. Specific root length (SRL) of three tall fescue cultivars as affected by drought stress. Columns with the same letters are not significantly different based on LSD $(P \leq 0.05)$. Lowercase letters indicate treatment comparisons within a given cultivar, and uppercase letters indicate culti 
Table 1. Nutrient concentrations $\left(\mathrm{mg} \cdot \mathrm{g}^{-1}\right)$ in shoots and roots of three tall fescue cultivars after $35 \mathrm{~d}$ of drought.

\begin{tabular}{|c|c|c|c|c|c|c|c|c|c|c|}
\hline \multirow[b]{2}{*}{ Cultivar } & \multirow[b]{2}{*}{ Treatment } & \multicolumn{6}{|c|}{ Shoots } & \multicolumn{3}{|c|}{ Roots } \\
\hline & & $\mathrm{N}$ & $\mathrm{P}$ & $\mathrm{K}$ & $\mathrm{Mg}$ & $\mathrm{Ca}$ & $\mathrm{Fe}$ & $\mathrm{N}$ & $\mathrm{P}$ & $\mathrm{K}$ \\
\hline \multirow[t]{3}{*}{ Falcon } & Watered & 27.6 & $4.2 b^{z}$ & $20.9 \mathrm{c}$ & 2.9 & 5.3 & $0.36 \mathrm{c}$ & 14.1 & 1.6 & $10.8 \mathrm{a}$ \\
\hline & Drought & 18.9 & $2.8 \mathrm{c}$ & $32.3 \mathrm{a}$ & 2.5 & 5.9 & $0.48 \mathrm{~b}$ & 13.4 & 1.3 & $4.8 \mathrm{~b}$ \\
\hline & Mean & 23.3 & $\underline{3.5}$ & $\underline{26.2}$ & 2.7 & $\underline{5.6}$ & $\underline{0.42}$ & $\underline{13.8}$ & $\underline{1.5}$ & $\underline{7.8}$ \\
\hline \multirow[t]{3}{*}{ Houndog } & Watered & 26.9 & $4.7 \mathrm{ab}$ & $26.1 \mathrm{~b}$ & 2.8 & 5.0 & $0.39 \mathrm{c}$ & 14.4 & 1.6 & $10.0 \mathrm{a}$ \\
\hline & Drought & 19.3 & $2.7 \mathrm{c}$ & $31.2 \mathrm{a}$ & 2.5 & 5.6 & $0.65 \mathrm{a}$ & 13.0 & 1.2 & $3.6 \mathrm{c}$ \\
\hline & Mean & 23.1 & $\underline{3.7}$ & $\underline{28.7}$ & $\underline{2.7}$ & $\underline{5.3}$ & $\underline{0.52}$ & $\underline{13.7}$ & $\underline{1.4}$ & $\underline{6.8}$ \\
\hline \multirow[t]{3}{*}{ Rebel Jr } & Watered & 28.8 & $4.9 \mathrm{a}$ & $\overline{25.2} \mathrm{~b}$ & 2.9 & $\overline{5.0}$ & $\overline{0.34} \mathrm{c}$ & $\overline{13.8}$ & 1.8 & $10.4 \mathrm{a}$ \\
\hline & Drought & 18.4 & $2.2 \mathrm{~d}$ & $28.0 \mathrm{~b}$ & 2.4 & 5.3 & $0.64 \mathrm{a}$ & 13.7 & 1.2 & $3.0 \mathrm{c}$ \\
\hline & Mean & $\underline{23.6}$ & $\underline{3.6}$ & $\underline{26.6}$ & $\underline{2.7}$ & $\underline{5.2}$ & $\underline{0.49}$ & $\underline{13.8}$ & $\underline{1.5}$ & $\underline{6.7}$ \\
\hline \multirow[t]{2}{*}{ Mean } & Watered & 27.8 & 4.6 & 24.1 & 2.9 & 5.1 & 0.36 & 14.1 & 1.7 & 10.4 \\
\hline & Drought & 18.9 & 2.6 & 30.5 & 2.5 & 5.6 & 0.59 & 13.4 & 1.2 & 3.8 \\
\hline \multirow[t]{3}{*}{ ANOVA } & Treatment $(\mathrm{T})$ & $* *$ & $* *$ & $* *$ & **** & $*$ & $* * *$ & NS & $*$ & $* * *$ \\
\hline & Cultivar (C) & NS & $*$ & $*$ & NS & NS & $*$ & NS & NS & $*$ \\
\hline & $\mathrm{T} \times \mathrm{C}$ & NS & $*$ & $*$ & NS & NS & $*$ & NS & NS & $*$ \\
\hline
\end{tabular}

${ }^{\mathrm{z}}$ Within columns, mean separation among all treatments by $\mathrm{LSD}_{0.05}$.

Ns, ${ }^{*},{ }^{* *},{ }^{* * *}$ Nonsignificant or significant at $P \leq 0.05,0.01$, or 0.001 , respectively.

trations of $\mathrm{N}, \mathrm{P}, \mathrm{Mg}, \mathrm{Ca}$, and Fe did not differ among cultivars.

Root nutrient status. Drought stress had no significant effects on $\mathrm{N}$ concentration in roots, but reduced $\mathrm{P}$ in 'Rebel Jr' and $\mathrm{K}$ concentration in all three cultivars (Table 1). No cultivar differences in $\mathrm{N}$ and $\mathrm{P}$ concentrations in roots were detected under drought conditions. Although roots of drought-stressed 'Falcon II' had significantly higher $\mathrm{K}$ concentration than did those of 'Rebel Jr', they did not differ from those of 'Houndog V'.

Nutrient allocation. The proportions of $\mathrm{N}$ and $\mathrm{P}$ in shoots decreased relative to their respective controls for all three cultivars (Fig. 3 ). In contrast, the proportion of $\mathrm{K}$ in shoots of each cultivar increased in drought-stressed plants in relation to that of well-watered controls.

\section{Discussion}

Responses of photosynthesis and water relations to drought stress previously reported by Huang and Gao (1999) suggest that drought resistance of 'Houndog V' and 'Falcon II' is superior to that of 'Rebel Jr'. Better drought tolerance of tall fescue cultivars has been attributed to: 1) low basal osmotic potential before stress; 2) osmotic adjustment; 3) prolonged turgor maintenance (White et al., 1992, 1993);4) high photosynthetic capacity (Huang and Gao, 1999); and 5) deep rooting (Carrow, 1996; Huang and Fry, 1998; Huang and Gao, 2000; Qian and Fry, 1997). In the present study, nutrient analysis indicated that relatively tolerant cultivars were able to maintain accumulations of $\mathrm{K}$ and $\mathrm{P}$ and avoid accumulation of $\mathrm{Fe}$ during drought stress.

Effects of drought stress on responses of nutrient status have been inconsistent among various studies. Decreased, unchanged, or even increased nutrient concentrations in shoots and roots have been found under droughtstress conditions, depending on the plant species and ion involved. Nawar and Ezz (1993)

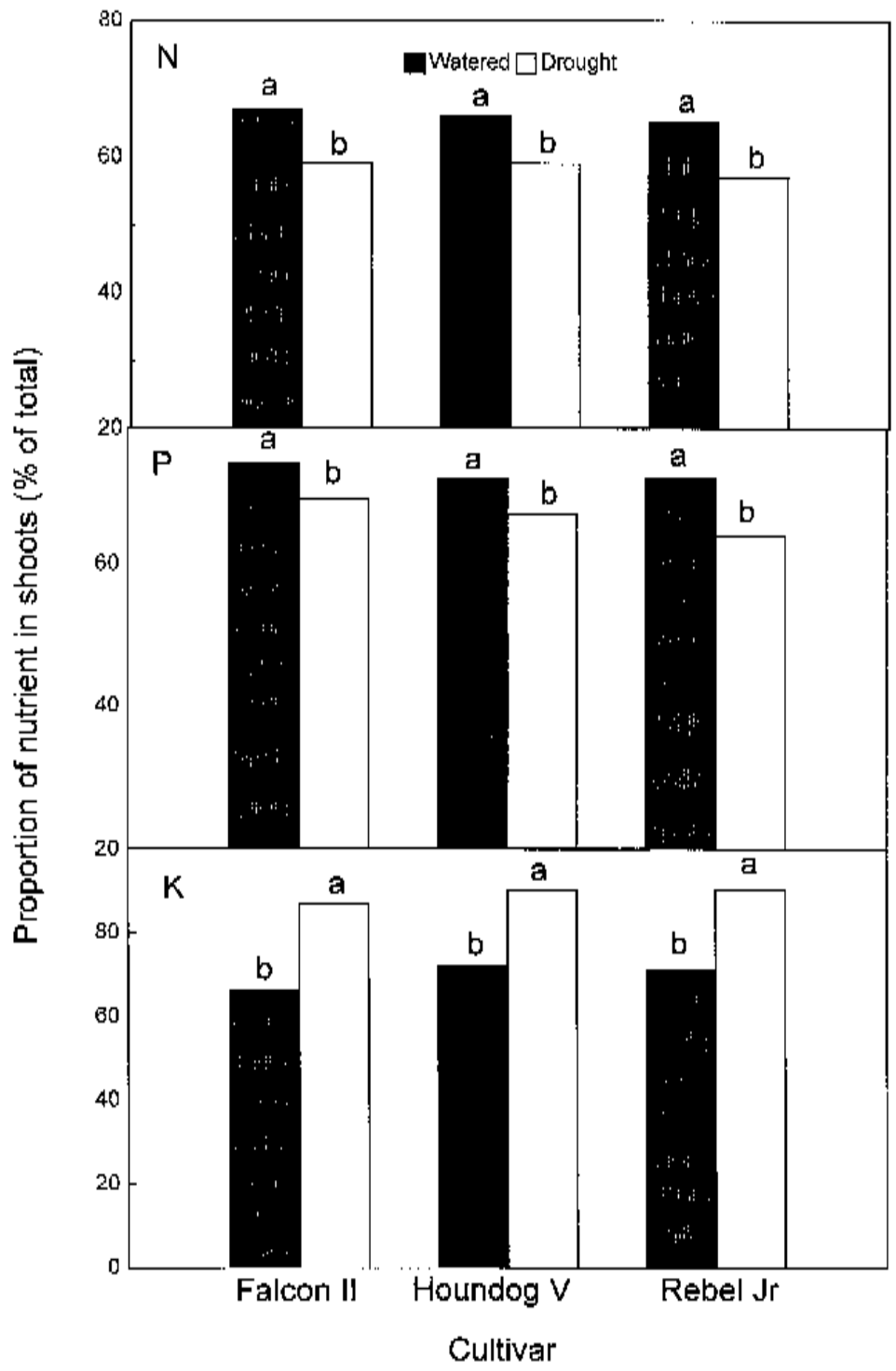

Fig. 3. Content of N, P, and $\mathrm{K}$ in shoots as a proportion of total amount in whole plants of 'Falcon II', 'Houndog V', and 'Rebel Jr' as affected by drought stress. Mean separation within elements, organs, and cultivars by $\mathrm{LSD}_{0.05}$. 
reported that water stress lowered $\mathrm{P}, \mathrm{K}, \mathrm{Ca}$, and $\mathrm{Mg}$ concentrations in apricot (Prunus armeniaca $\mathrm{L}$.) leaves, but increased $\mathrm{P}$ concentration while reducing $\mathrm{K}$ concentration in roots. Itoh and Kumura (1990) observed that when soil water content decreased, $\mathrm{K}$ concentration in soybean [Glycine max (L.) Merrill] leaves increased and remained high under low moisture conditions, whereas root $\mathrm{K}$ concentration decreased. Krizek and Foy (1982) found that drought stress significantly increased Ca concentration in two cultivars of barley (Hordeum vulgare $\mathrm{L}$.); $\mathrm{P}$ was reduced in one cultivar and $\mathrm{Mg}$ was unaffected in both cultivars. Turner (1985) also reported reduced $P$ levels in leaves of Capsicum annum L. under a mild degree of drought stress. Wilkinson et al. (1989), however, noted increased $\mathrm{K}, \mathrm{Ca}$, and $\mathrm{Mg}$ concentrations in response to water stress. ElMonayeri et al. (1984) also found increased K, $\mathrm{Mg}$, and $\mathrm{Ca}$, but decreased $\mathrm{Fe}$ and $\mathrm{P}$ concentrations in barley with increasing drought stress. Heckathorn and Delucia (1994) reported that $\mathrm{N}$ concentration of shoots and roots decreased during drought in several $\mathrm{C}_{4}$ grass species.

In the present study, changes in nutrient concentration in response to drought stress varied with elements, plant parts, and cultivars. The concentrations of $\mathrm{N}, \mathrm{P}$, and $\mathrm{Mg}$ in shoots and of $\mathrm{K}$ in roots decreased under drought stress in all three cultivars. The reduction in each nutrient element was more pronounced for 'Rebel Jr' than for 'Falcon II' and 'Houndog V'. The severity of drought-induced reduction in nutrient concentration of the shoot was in the order $\mathrm{P}>\mathrm{N}=\mathrm{Mg}$. Limited accumulations of $\mathrm{N}$ and $\mathrm{P}$ may have been a result of restricted nutrient transport; under drought conditions the proportions of $\mathrm{N}$ and $\mathrm{P}$ decreased in shoots, but increased in roots. Low $\mathrm{N}, \mathrm{P}$, and $\mathrm{Mg}$ concentrations in shoots could also be due to the inhibitory effects of drought on nutrient uptake capacity. Drought can inhibit nutrient uptake by reducing: 1) transpiration (Greenway and Klepper, 1969; Yambao and O'Toole, 1984); 2) diffusion rate of nutrients from the soil to the absorbing root surface (Barber, 1962; Marais and Weirsma, 1975); and 3) root membrane permeability and growth (Hsiao, 1973). The decline in shoot $\mathrm{N}$ also has been attributed to retranslocation from shoots to roots or rhizomes in $\mathrm{C}_{4}$ grasses (Heckathorn and DeLucia, 1994).

The relatively drought-tolerant 'Falcon II' maintained significantly higher $\mathrm{P}$ in shoots than did the relatively intolerant 'Rebel Jr' under drought conditions; this could be related to the greater total root length and higher SRL of 'Falcon II'. Generally, specific root length is negatively related to root diameter (Eissenstat, 1992). The increases in SRL under drought conditions indicated that more fine roots were produced. Fine roots have high surface area per unit weight, which may enhance acquisition of nutrients, particularly less mobile nutrients such as $\mathrm{P}$, in the drying soil (Mackay and Barber, 1985, 1987).

Drought increased $\mathrm{K}, \mathrm{Ca}$, and $\mathrm{Fe}$ concentrations in shoots of all three cultivars. Also, the ratio of $\mathrm{K}$ in shoots to the total $\mathrm{K}$ in the whole plant increased, but that in roots decreased. This response suggests that during water stress, roots may act as a reservoir that supplies $\mathrm{K}$ to the leaves preferentially. Also, drought favors osmotic adjustment in shoots, which could enhance maintenance of leaf turgor. Under drought stress, concentrations of K were higher in shoots of 'Falcon II' and 'Houndog V' and in roots of 'Falcon II' than in comparable organs of 'Rebel Jr'. Sinha (1978) also observed that drought-tolerant wheat (Triticum aestivum L.) cultivars can accumulate more $\mathrm{K}$ than do the susceptible cultivars. The accumulation of K could contribute to osmotic adjustment, as suggested by Jones et al. (1980). Increasing K concentration results in active osmotic adjustment and, consequently, increased cellular turgor potentials in drying soil (Eakes et al., 1991). The concentration of $\mathrm{Ca}$ in tall fescue shoots increased during drought stress, although cultivars did not differ. Increases in Ca concentration in shoots of plants growing under stress has been reported previously (Antolin and Sanchez-Diaz, 1992; Jones, 1985; Utrillas et al., 1995). The accumulation of Ca, like K, also could contribute to osmotic adjustment (Stow, 1989).

Increases in Fe during drought stress have been reported by (Al-Karaki et al., 1998; Price and Hendry, 1989). This accumulation could damage cells by activating lipid peroxidation of cell membranes (Price and Hendry, 1991). Superoxide (or its dismuted product $\mathrm{H}_{2} \mathrm{O}_{2}$ ) reacts in the presence of $\mathrm{Fe}^{2+}$ to form the highly destructive hydroxyl radical $(\mathrm{OH})$ via the Fenton reaction or the iron-catalyzed HaberWeiss cycle (see Halliwell and Gutteridge, 1990). A smaller increase in $\mathrm{Fe}^{2+}$ in 'Falcon II' compared with 'Rebel Jr' under drought conditions could contribute to its better drought tolerance.

In summary, nutrient responses of tall fescue to drought stress varied with elements, plant parts, and cultivars. Deficiency of $\mathrm{P}$ was more likely to occur than deficiencies of other nutrients. Drought favored N and P allocations to roots and $\mathrm{K}$ allocation to shoots. The increased accumulation of $\mathrm{K}$ and decreased accumulation of $\mathrm{Fe}$ in shoots could contribute to better drought tolerance.

\section{Literature Cited}

Al-Karaki, G.N. Al-Raddad, and R.B. Clark. 1998. Water stress and mycorrhizal isolate effects on growth and nutrient acquisition of wheat. J. Plant Nutr. 21:891-902.

Antolin, M.C. and M. Sanchez-Diaz. 1992. Photosynthetic nutrient use efficiency, nodule activity and solute accumulation in drought stressed alfalfa plants. Photosynthethica 27:595-604.

Barber, S.A. 1962. A diffusion and mass-flow concept of soil nutrient availability. Soil Sci. 93:39-49.

Beard, J.B. 1989. Turfgrass water stress: Drought resistance components, physiological mechanisms, and species-genotype diversity, p. 2328. In: H. Takatoh (ed.). Proc. $6^{\text {th }}$ Intl. Turf. Sci. Soc., Japan. Soc. Turf. Sci. Tokyo.

Carrow, R.N. 1996. Drought avoidance characteristics of diverse tall fescue cultivars. Crop Sci. 36:371-377.
Eakes, D.J., R.D. Wright, and J.R. Seiler. 1991. Water relations of Salvia splendens 'Bonfire' as influenced by potassium nutrition and moisture stress conditioning. J. Amer. Soc. Hort. Sci. 116:712-715.

Eissenstat, D.M. 1992. Costs and benefits of constructing roots of small diameter. J. Plant Nutr. 15:763-782.

El-Monayeri, M.O., F.A. Ebaid, M.M. Youssef, and H.M. Salem. 1984. Effect of soil moisture stress on carbohydrates, proteins and mineral composition of three barley varieties. J. College Sci., King Saud Univ. 15:97-111.

Greenway, H. and B. Klepper. 1969. Relation between anion transport and water flow in tomato plants. Physiol. Plant. 22:208-219.

Halliwell, B. and J.M.C. Gutteridge. 1990. Free radicals in biology and medicine, $2^{\text {nd }}$ ed. Clarendon Press, Oxford.

Heckathorn, S.A. and E.H. DeLucia. 1994. Droughtinduced nitrogen retranslocation in perennial $\mathrm{C}_{4}$ grasses of tallgrass prairie. Ecology 75:18771886.

Heckathorn, S.A., E.H. DeLucia, and R.E.Zielinski. 1997. The contribution of drought-related decreases in foliar nitrogen concentration to decrease in photosynthetic capacity during and after drought in prairie grasses. Plant. Physiol. 101:173-182

Hsiao, T.C. 1973. Plant responses to water stress. Annu. Rev. Plant Physiol. 24:519-570.

Huang, B. 1998. Water relations and root activities of Buchloe dactyloides and Zoysia japonica in response to localized soil drying. Plant and Soil 208:170-186.

Huang, B., R.R. Duncan, and R.N. Carrow. 1997. Drought resistance mechanisms of seven warmseason turfgrasses under surface soil drying: II. Root aspects. Crop Sci. 37:1863-1869.

Huang, B. and J.D. Fry 1998. Root anatomical, morphological, and physiological responses to drought stress for tall fescue cultivars. Crop Sci. 38:1017-1022.

Huang, B., J.D. Fry, and B. Wang. 1998. Water relations and canopy characteristics of tall fescue cultivars during and after drought stress. HortScience 33:837-840.

Huang, B. and H. Gao. 1999. Physiological responses of diverse tall fescue cultivars to drought stress. HortScience 34:897-901.

Huang, B. and H. Gao. 2000. Root characteristics associated with drought resistance in tall fescue. Crop Sci. 40. (In press.)

Itoh, R. and A. Kumura. 1990. Acclimation of soybean plants to water deficit. VI. Analysis of regulation of tissue potassium concentration in leaves and stems. Jpn. J. Crop Sci. 59:824-829.

Jones, C.A. 1985. C 4 Grasses and cereals. Growth, development and stress response. Wiley, New York.

Jones, M.M., C.B. Osmond, and N.C. Turner. 1980. Accumulation of solutes in leaves of sorghum and sunflower in response to water deficits. Aust. J. Plant Physiol. 7:193-205.

Krizek, D.T. and C.D. Foy. 1982. Elemental content of two barley cultivars in relation to water stress and aluminum toxicity, p. 304. In: A. Scaife (ed.). Proc. $9^{\text {th }}$ Int. Plant Nutr. Colloq. Warwick Univ., England.

Mackay, A.D. and S.A. Barber. 1985. Soil moisture effect on potassium uptake by corn. Agron. J. 77:519-523.

Mackay, A.D. and S.A. Barber. 1987. Effect of cyclic wetting and drying of a soil on root hair growth of maize. Plant Soil. 104:291-300.

Marais, J.N. and D. Wiersma. 1975. Phosphorus uptake by soybeans as influenced by moisture stress in the fertilized zone. Agron. J. 67:777781 
Marcum, K.B., M.C. Engelke, S.J. Morton, and R.H. White. 1995. Rooting characteristics and associated drought resistance of Zoysiagrass. Agron. J. 87:534-538.

Matzner, S.L. and J.H. Richards. 1996. Sagebrush (Artemisia tridentata Nutt.) roots maintain nutrient uptake capacity under water stress. J. Expt. Bot. 47:1045-1056.

McKenzie, H.A. 1953. The Kjeldahl determination of nitrogen. A critical study of digestion conditions, temperature, catalyst, and oxidation agent. Aust. J. Chem. 7:55-70.

Nawar, A. and T. Ezz. 1993. Leaf and root mineral composition as well as nitrogen and phosphorous metabolism in apricot seedlings grown under different soil moisture levels. Alexandria J. Agr. Res. 38:355-373.

Price, A.H. and G.A.F. Hendry. 1989. Stress and the role of activated oxygen scavengers and protective enzymes in plants subjected to drought. Biochem. Soc. Trans. 17:493-494.
Price, A.H. and G.A.F. Hendry. 1991. Ironcatalysed oxygen radical formation and its possible contribution to drought damage in nine native grasses and three cereals. Plant Cell Environ. 14:477-484.

Qian, Y. and J.D. Fry. 1997. Rooting and drought avoidance of warm-season turfgrasses and tall fescue in Kansas. Crop Sci. 37:905-910.

Sheffer, K.M., J.H. Dunn, and D.D. Minner. 1987. Summer drought responses and rooting depth of three cool-season turfgrasses. HortScience 22:296-297.

Sinha, S.K. 1978. Influence of potassium on tolerance to stress, p. 223-242. In: G.S. Sekhon (ed.). Potassium in soils and crops. Potash Res. Inst., New Delhi, India.

Stow, J. 1989. The involvement of calcium ions in maintenance of apple fruit tissue structure. $\mathbf{J}$. Expt. Bot. 40:1053-1057.

Turner, L.B. 1985. Changes in the phosphorus content of Capsicum annuum leaves during water stress. J. Plant. Physiol. 121:429-439.

Utrillas, M.J., L. Alegre, and E. Simon. 1995. Seasonal changes in production and nutrient content of Cynodon dactylon (L.) Pers. subjected to water deficits. Plant Soil 175:153157.

White, R.H., A.H. Bruneau, and T.J. Cowett. 1993. Drought resistance of diverse tall fescue cultivars. Intl. Turf. Soc. Res. J. 7:607-613.

White, R.H., M.C. Engelke, S.J. Morton, and B.A Ruemmele. 1992. Competitive turgor maintenance in tall fescue. Crop Sci. 32:251-256.

Wilkinson, S.R., D.F. Belesky, and W.C. Stringer. 1989. Effect of endophytic fungus infection, water stress and genotype on $\mathrm{K}, \mathrm{Ca}$ and $\mathrm{Mg}$ concentration of fescue. Proc. XVII Intl. Grassland Congr. Nice, France.

Yambao, E.B. and J.C. O'Toole. 1984. Effects of nitrogen nutrition and root medium water potential on growth, nitrogen uptake and osmotic adjustment of rice. Physiol. Plant. 60:507-515. 